\title{
Kafka no Brasil: 1946-1979
}

\section{Kafka in Brazil: 1946-1979}

\section{Denise Bottmann*}

Resumo: Este artigo aborda três temas referentes à presença de Kafka no Brasil. Primeiramente, como algumas traduções espanholas anônimas foram atribuídas a J orge Luis Borges e foram utilizadas em diversas traduções brasileiras. A seguir, uma demonstração de que a língua de interposição utilizada por Torrieri Guimarães, o mais prolífico tradutor de Kafka entre nós, foi o espanhol. Por fim, um levantamento dos textos de Kafka traduzidos e publicados no Brasil entre 1946 e 1979.

Palavras-chave: Kafka; história da tradução no Brasil; literatura de língua alemã.

Abstract: This article addresses three aspects of Kafka's presence in Brazil: firstly, how some anonymous Spanish translations were attributed to J orge Luis Borges and used in several Brazilian translations; secondly, a demonstration that the intermediary language used by Torrieri Guimarães, our most prolific translator of Kafka, was Spanish; and, finally, a survey of texts by Kafka that were translated and published in Brazil between 1946 and 1979.

Keywords: Kafka; history of translation in Brazil; German-language literature.

\footnotetext{
* Pesquisadora de história da tradução no Brasil
} 
Um dos casos mais interessantes na história da tradução no Brasil é o de Franz Kafka, cujas décadas iniciais entre nós compõem um quadro permeado de dúvidas, incertezas e até historietas mal contadas. É sobre este quadro que nos debruçaremos para dirimir algumas dessas dúvidas e esclarecer algumas dessas incertezas, sem deixar de reconstituir também algumas dessas curiosas historietas.

\section{Da Espanha ao Brasil, via Argentina}

Comecemos pela Espanha nos anos 1920, destacando um episódio que, passando pela Argentina, refletiu-se no Brasil nos anos 1940, desde então ganhando amplitude e sólida permanência na kafkiana brasileira.

Em 1925, a Revista de Occidente, célebre publicação madrilenha dirigida por Ortega y Gasset, lançou a primeira tradução de Die Verwandlung de que se tem notícia no mundo, que recebeu em espanhol o título de La metamorfosis. A novela saiu em duas partes, no primeiro e no segundo semestres daquele ano. A tradução era anônima e perdeu-se a memória de quem a teria feito na época.

Em 1927, a mesma Revista de Occidente publicou, também anonimamente, a tradução de "Ein Hungerkünster" com o título de "Un artista del hambre". E, em 1932, lançou "Erstes Leid" com o título de "Un artista del trapecio", " tampouco trazendo identificação do tradutor.

Em 1938, a editora Losada de Buenos Aires inaugurou sua coleção "La pajarita de papel". 0 autor escolhido para estrear a coleção foi Kafka, com uma coletânea de textos reunidos sob o título de La metamorfosis. A seleta trazia

\footnotetext{
${ }^{1}$ Comente-se de passagem que, se o título "Un artista del trapecio", tão distante do original Erstes Leid, parece corresponder a uma escolha da revista para traçar alguma linha de continuidade na mente do leitor com "Un artista del hambre" publicado alguns anos antes, por outro lado ele adquirirá foros de cidadania quase permanente entre nós, servindo até como uma espécie de fio de Ariadne para a pesquisa das fontes da tradução.
} 
BottmanN, D. - Kafka no Brasil: 1946-1979

nove contos, a saber: "La metamorfosis", "La edificación de la Muralla China", "Un artista del hambre", "Un artista del trapecio", "Una cruza", "El buitre",

"El escudo de la ciudad", "Prometeo" e "Una confusión cotidiana". Tradutor: J orge Luis Borges.

Porém, as traduções de "La metamorfosis", "Un artista del trapecio" e "Un artista del hambre" assinadas por Borges em 1938 são réplicas praticamente intocadas das traduções anônimas publicadas em 1925-1927 pela Revista de Occidente. Transcorreram-se quase quarenta anos até que J orge Luis Borges viesse a admitir que a tradução de "La metamorfosis" publicada pela Losada não era de lavra sua.

Foi o professor e tradutor Fernando Sorrentino, grande apreciador de Kafka e de Borges, quem deslindou o enigma. Ao ler nos anos 1960 o volume da Losada, La metamorfosis, estranhara aquela versão da novela-título, parecendo-Ihe muito distante dos "costumes lexicais e sintáticos de Borges". Comenta ele: "No se trataba de la presión que el texto original ejerce sobre el traductor, obligándolo a adecuarse, en mayor o menor medida, a las características del autor traducido. La divergencia estilística era abismal: resulta extrañísimo que nadie se haya dado cuenta de que tal traducción no era, ni podía ser, obra de Borges" (SORRENTINO 2000).

Em 1970, Sorrentino teve ocasião de realizar diversas entrevistas com Borges, das quais resultou o livro Siete conversaciones con J orge Luis Borges, publicado em $1974 .^{2}$ Foi então que pôde dirimir sua dúvida, comentando diretamente com Borges:

F.S.: Me pareció notar en su versión de La metamorfosis, de Kafka, que usted difiere de su estilo habitual...

J.L.B.: Bueno: ello se debe al hecho de que yo no soy el autor de la traducción de ese texto. Y una prueba de ello -además de mi palabra - es que yo conozco algo de alemán, sé que la obra se titula Die Verwandlung y no Die Metamorphose, y sé que hubiera debido traducirse como La transformación. (...) Lo que yo sí traduje fueron

2 volume foi lançado no Brasil como Jorge Luís Borges: sete conversas com Fernando Sorrentino, em tradução de Ana Flores, pela Azougue Editorial, em 2009. 
los otros cuentos de Kafka que están en el mismo volumen publicado por la editorial Losada. Pero, para simplificar -quizá por razones meramente tipográficas-, se prefirió atribuirme a mí la traducción de todo el volumen, y se usó una traducción acaso anónima que andaba por ahí. (Id., ibid.)

Naquela ocasião Sorrentino se deu por satisfeito, pois, segundo ele, o que the interessava na época era apenas comprovar que a tradução não era de Borges, e não descobrir qual seria, de quem seria ou onde teria sido publicada a misteriosa tradução. Porém, tempos depois, vindo a saber que tampouco "Un artista del hambre" e "Un artista del trapecio" tinham sido traduzidos por Borges, decidiu por fim "tratar de encontrar la 'traducción acaso anónima que andaba por ahí' (y que, sin duda, Borges siempre supo cuál era y dónde estaba)". E foi então que suas pesquisas o levaram à Revista de Occidente e aos números anteriormente citados. ${ }^{3}$

Deixando as digressões sobre a fortuna argentina de Kafka, passemos agora ao que aconteceu no Brasil com esses três contos.

Em 30 de março de 1946, a Revista da Semana, Ano XLVII, no. 13, publicou aquela que parece ser a primeira tradução de Kafka entre nós, a saber, "Um artista do trapézio", anônima e sem indicação de fontes. À sua leitura, vê-se claramente que ela se baseou na citada tradução em espanhol.

Em 1947, mais precisamente no dia 31 de agosto, o jornal Diário de Notícias, em sua coluna "Conto da Semana", publica uma nova tradução de "Um artista do trapézio", agora por Aurélio Buarque de Hollanda, o qual especifica devidamente que utilizou como base a edição da Losada com tradução em nome de J orge Luis Borges.

Na década seguinte, em 1957, a editora Cultrix, no volume Maravilhas do conto alemão, também publica "O artista do trapézio". Tradução? Anônima.

\footnotetext{
${ }^{3}$ Para o debate de Sorrentino e outros em torno da questão, bem como para algumas hipóteses sobre a identidade do tradutor anônimo, veja-se «ttp:// naogostodeplagio. blogspot.com. br/ 2009/ 11/ kafka-anonimo-borgiano. html>.
} 
A essas alturas, o leitor já terá adivinhado, e corretamente, que esse artista do trapézio também é aquele mesmo publicado na Revista de Occidente.

Chegando à década de 1960, temos o que se poderia considerar a primeira grande alavancada na difusão das obras de Kafka no Brasil, basicamente por iniciativa da Livraria Exposição do Livro (L.E.L., posterior Hemus), com traduções feitas sempre por Torrieri Guimarães.

Um de seus volumes, A colônia penal, publicado em 1965, traz 39 contos, entre eles "A metamorfose", "Um artista da fome" e "Um artista do trapézio". Por mais que seu tradutor, Torrieri Guimarães, afirmasse que fazia suas traduções de Kafka por interposição do francês - tema do qual trataremos mais adiante -, a verdade é que esses três contos são fielmente calcados nas traduções em espanhol. A este respeito, vale lembrar o excelente estudo de Celso Cruz (2007), apontando como era "visível a ligação do texto assinado por Torrieri com as versões hispânicas" (CRUZ, 2007: 201).

Eis uma breve comparação:

Ao despertar Gregorio Samsa una mañana, tras un sueño intranquilo, encontróse en su cama convertido en un monstruoso insecto. Hallábase echado sobre el duro carapazón de su espalda y, al alzar un poco la cabeza, vio la figura convexa de su vientre oscuro, surcado por curvadas callosidades, cuya prominencia apenas si podía aguantar la colcha, que estaba visiblemente a punto de escurrirse hacia el suelo. Innumerables patas, lamentablemente escuálidas en comparación con el grosor ordinario de sus piernas, of recían a sus ojos el espectáculo de una agitación sin consistencia. ("J LB")

Quando, certa manhã, Gregório Samsa despertou, depois de um sono intranquilo, achou-se em sua cama convertido em um monstruoso inseto. Achava-se deitado sobre a dura carapaça de suas costas, e, ao erguer um pouco a cabeça, viu a figura convexa de seu ventre escuro, sulcado por pronunciadas ondulações, cuja proeminência a colcha mal podia aguentar, que estava visivelmente a ponto de escorrer até o solo. Inúmeras patas, lamentavelmente esquálidas em comparação com a grossura comum de suas pernas, ofereciam a seus olhos 0 espetáculo de uma agitação sem consistência. (TG) 
Eis mais duas breves comparações entre trechinhos traduzidos de, respectivamente, "Ein Hungerkünster" e "Erstes Leid":

Para los adultos aquello solía no ser más que una broma en la que tomaban parte medio por moda, pero los niños, cogidos de las manos por prudencia, miraban asombrados y boquiabiertos a aquel hombre pálido, con camiseta oscura, de costillas salientes, que, desdeñando un asiento, permanecía tendido en la paja esparcida por el suelo, y saludaba, a veces, cortamente o respondía con forzada sonrisa a las preguntas que se le dirigían o sacaba, quizá, un brazo por entre los hierros para hacer notar su delgadez, volviendo después a sumirse en su propio interior, sin preocuparse de nadie ni de nada, ni siquiera de la marcha del reloj, para él tan importante, única pieza de mobiliario que se veía en su jaula. ("J LB")

Para os adultos aquilo costumava não ser senão uma brincadeira na qual tomavam parte meio por moda, mas as crianças, seguros [sic] pelas mãos por prudência, ol havam assombrados e boquiabertos aquele homem pálido, com camiseta escura, de costelas salientes, que, desdenhando um assento, permanecia estendido na palha esparsa pelo solo, e saudava, às vezes, cortesmente [sic] ou respondia com forçado sorriso às perguntas que dirigiam a ele, ou tirava, talvez, um braço por entre os ferros para fazer notar sua magreza, tornando depois a sumir-se em seu próprio interior, sem se preocupar por ninguém ou com nada, nem sequer pela marcha do relógio, para ele tão importante, única peça de mobiliário que se via em sua jaula. (TG)

E:

Un artista del trapecio - como se sabe, este arte que se practica en lo alto de las cúpulas de los grandes circos es uno de los más difíciles entre todos los asequibles al hombre- había organizado su vida de tal manera - primero por afán profesional de perfección, después por costumbre que se había hecho tirânica - que, mientras trabajaba en la misma empresa, permanecía día y noche en el trapecio. Todas sus necesidades - por otra parte muy pequenas - eran satisfechas por criados que se relevaban a intervalos y vigilaban debajo. Todo lo que arriba se necesitaba lo subían y bajaban en cestillos construidos para el caso. ("J LB")

Um artista do trapézio - como se sabe, esta arte que se pratica no alto das cúpulas dos grandes circos é uma das mais difíceis entre 
todas as exequíveis ao homem - tinha organizado sua vida de tal maneira - primeiro por afã profissional de perfeição, depois por costume que se tornara tirânico - que, enquanto trabalhava na mesma empresa, permanecia dia e noite no trapézio. Todas as suas necessidades - por outro lado muito pequenas - eram satisfeitas por criados que se revezavam em intervalos e vigiavam embaixo. Tudo 0 de que se precisava em cima subiam-no e baixavam em cestinhos construídos para o caso. (TG)

Assim, quanto a esses três contos de Kafka, provavelmente jamais saberemos quem foi seu legítimo tradutor, desde sua origem anônima na Espanha até 0 falseamento dos créditos de tradução na Argentina. $O$ fato adquire maior relevância, sobretudo em relação a A metamorfose, por ser, entre esses três textos, o mais amplamente divulgado entre nós na tradução de Torrieri Guimarães, com incontáveis edições entre diversas casas publicadoras: além da L.E.L., a Tecnoprint em "Clássicos de Ouro"; o Clube do Livro; a Ediouro em "Biblioteca de Babel"; a Publifolha em "Biblioteca Folha" (junto com "Um artista da fome"); a Ediouro em outro "Clássicos de Ouro"; a Itatiaia/ Villa Rica; a Martin Claret. ${ }^{4}$

\section{Nosso Kafka de origens poliglotas}

Vejamos agora por meio de quais línguas Kafka chegou ao Brasil.

No período que aqui nos interessa, de 1946 a 1979, traduziu-se muito do espanhol, bastante do inglês, um pouco do francês e praticamente nada do alemão. Poderíamos caracterizá-lo esquematicamente da seguinte maneira:

1. De 1946 a 1963, uma fase inicial de publicações dispersas e traduções a partir de fontes e idiomas variados, inclusive as únicas duas ou três possíveis ocorrências de traduções diretas do alemão.

\footnotetext{
${ }^{4}$ As edições de A metamorfose pela Martin Claret passaram anos envolvidas em irregularidades. Vejam-se CRUZ (2007: 205-6) e VIANNA (2007).
} 
2. De 1964 a 1979, quando se tem praticamente toda a obra de Kafka traduzida e publicada entre nós, podemos discernir duas fases nitidamente distintas: nos anos 1960, o predomínio maciço de traduções a partir do espanhol; nos anos 1970, o predomínio maciço de traduções a partir do inglês.

Tentemos agora rastrear as várias situações linguísticas e os vários canais por onde, de maneira mais sistemática, chegaram as obras de Kafka a nós.

Na seção anterior, vimos que um desses canais foi a coletânea de contos publicada pela Losada, utilizando sob o nome de J orge Luis Borges traduções anônimas anteriores de "A metamorfose", "Um artista da fome" e "Um artista do trapézio". Vimos também que este último recebeu no Brasil quatro traduções distintas entre 1946 e 1965 (anônima da R.S., Aurélio Buarque de Hollanda, anônima cultrixiana e Torrieri Guimarães), todas elas partindo da mesma tradução espanhola, e que os outros dois contos na pretensa versão de Borges foram traduzidos também por Torrieri, sem menção à fonte utilizada.

Como Torrieri Guimarães foi por muitos anos o principal tradutor de Kafka entre nós e ainda hoje suas traduções continuam a ser reeditadas, seu nome está indissociavelmente integrado à kafkiana brasileira: daí a importância de examinarmos com algum vagar sua relação com a obra de Kafka.

Torrieri nunca pretendeu tê-la traduzido do alemão. Pelo menos desde os anos 1980, em entrevistas à imprensa e a setores universitários, o tradutor afirmava que se valera do francês como idioma de partida. Detenho-me numa entrevista mais recente, prestada em 2003 ao pesquisador Eduardo Manoel de BRITo (2005, "Anexo", p. 365-75). A história é um tanto engraçada: segundo Torrieri, o proprietário da editora L.E.L., Eli Behar, teria conhecido pessoalmente Max Brod em Israel, negociando diretamente com ele os direitos de tradução da obra de Kafka no Brasil e Brod os teria cedido a título de cortesia a Behar. Não que essas afirmações façam sentido, visto que Brod não estaria na menor condição de negociar e muito menos de doar coisa alguma: já desde 0 começo dos anos 1930, ele transferira todos os direitos sobre as obras completas de Kafka em nível mundial para a Schocken, então ainda sediada em Berlim. Assim, desde 1934 a Schocken se tornou a detentora exclusiva dos direitos de 
edição, tradução e publicação mundial de todo o corpus kafkiano (aliás, no caso da Alemanha, a Schocken transferiu os direitos de publicação das obras de Kafka para S. Fischer apenas em 1951). Max Brod jamais voltou a deter qualquer direito sobre elas.

Mas, segundo Torrieri Guimarães apud BRITo (2005), foi nessas condições - com Max Brod cedendo gentilmente os direitos de tradução a Eli Behar - que se teria iniciado seu "intenso contato" com os textos do autor, ficando ele "à frente do projeto formal de traduzir toda a obra de Kafka para o português do Brasil" para a referida editora (125-6). Seu proprietário, Eli Behar, então teria fornecido os exemplares das obras de Kafka em francês a Torrieri para usá-las como base para suas traduções (160).

$\mathrm{Na}$ verdade, é tudo bem mais simples. Cruz apontou os inequívocos vínculos hispânicos, citados mais acima. De minha parte, rastreei esses vínculos até Borges e, via Sorrentino, até a Revista de Occidente. Prosseguindo as pesquisas das fontes primárias, não foi difícil constatar um fato muito evidente: todas as traduções de Kafka feitas por Torrieri Guimarães foram inequivocamente realizadas a partir do espanhol.

Vejamos, pois. Detenhamo-nos de início no volume que reúne os três textos que comentamos até agora. Trata-se de A colônia penal, como dissemos, publicada pela L.E.L. Apresenta 39 textos, distribuídos em cinco seções:

I. A Sentença, com "Narração" e "Aeroplanos em Bréscia";

II. Contemplação, com "Meninos em um caminho de campo", "Desmascaramento de um embaidor", "O passeio repentino", "Resoluções", "A excursão à montanha", "Infelicidade de solteiro", "O comerciante", "Contemplação distraída à janela", "Caminho para casa", "Transeuntes", "Companheiros de Viagem", "Vestidos", "A recusa", "Para que os cavalheiros meditem", "A janela para a rua", "O desejo de ser pele-vermelha", "As árvores" e "Infelicidade";

III. Um Médico Rural - Relatos Breves, com "Um novo advogado", "Um médico rural", "Na galeria", "Um velho manuscrito", "Diante da lei", "Chacais e árabes", "Uma visita à mina", "O povoado mais próximo", "Uma mensagem 
imperial", "Preocupações de um chefe de Família", "Onze filhos", "Um fratricídio", "Um sonho", "Informação para uma academia" e "Na colônia penal";

IV. Um Artista da Fome, com "Uma mulherzinha", "Um artista da fome", "Um artista do trapézio", "A metamorfose" e "J osefina, a cantora ou A cidade dos ratos";

V. Apêndice, com "Capítulo primeiro do livro Ricardo e Samuel", trazendo "Nota preliminar" e "A primeira viagem longa em trem", e "Três críticas", a saber, "Uma novela da juventude", "Sobre as anedotas de Kleist" e "Hyperion".

Ora, ainda que Torrieri afirme que a seleção dos 39 textos ficou a seu cargo e "escolheu a sequência dos contos" (BRITo 2005: 366), o conteúdo da coletânea corresponde ao do volume Erzählungen und kleine Prosa, isto é, o primeiro volume de Gesammelte Schriften, as obras reunidas a cargo de Max Brod, que foi publicado pela Schocken Verlag em Berlim, em 1935. A única diferença é a exclusão das duas conversas da "Descrição de uma luta", por uma simples e provável razão que será aventada adiante.

Assim, causa certa surpresa que o entrevistador de Torrieri tenha aceitado de plano suas declarações, afirmando: "Esta edição traduzida e organizada por Torrieri Guimarães corresponde a uma miscelânea de textos kafkianos, numa ordem pensada pelo tradutor, incluindo obras de vários e diferentes períodos da produção do autor tcheco e de diferentes matizes. A edição, portanto, não prima por uma orientação de cunho crítico-literário" (BRITO 2005: 125, negritos meus). Ora, mas se Erzählungen und kleine Prosa é justamente 0 volume das obras reunidas que congrega toda a produção que Kafka publicou em vida, e foi precisamente este o critério explícito - a publicação em vida - que Max Brod adotou como "orientação de cunho críticoliterário" para sua organização!

Esclarecido o equívoco, prossigamos.

Então, em 1952, Erzählungen und kleine Prosa foi publicado pela editora argentina Emecé, em sua coleção "Grandes Novelistas", com tradução direta 
BotTMAnN, D. - Kafka no Brasil: 1946-1979

do alemão feita por J uan Rodolfo Wilcock, sob o título geral de La condena. Ocorre que essa edição apresenta um dado curioso: mesmo indicando claramente o volume original a que deveria corresponder La condena, a Emecé excluiu de sua edição os três contos lançados pela Losada em sua coletânea de 1938, aqueles mesmos cuja tradução espanhola anônima fora atribuída a J orge Luis Borges - a Metamorfose e os dois Artistas, o da fome e o do trapézio.

E aí surge uma situação compósita interessante. A tradução de Torrieri em A colônia penal se calca na tradução de Wilcock em La condena pela Emecé; mas, tendo essa edição argentina excluído as três narrativas citadas, para elas Torrieri utilizou como texto de base - conforme apontei mais acima - a edição da Losada com a pretensa tradução de Borges.

Estes três contos, já vimos demoradamente. Mostremos, agora, que a tradução de Torrieri Guimarães para os demais contos de A colônia penal se calca na tradução de Wilcock em La condena. Por problemas de limitação de espaço, apresentaremos apenas um breve exemplo a título ilustrativo, extraído de "En la colónia penitenciaria/ Na colônia penal":

- Es un aparato singular - dijo el oficial al explorador, y contempló con certa admiración el aparato, que le era tan conocido. El explorador parecía haber aceptado sólo por cortesía la invitación del comandante para presenciar la ejecución de un soldado condenado por desobediencia e insulto hacia sus superiores. En la colónia penitenciaria no era tampoco muy grande el interés suscitado por esta ejecución. Por lo menos, en ese pequeño valle, profundo y arenoso, rodeado totalmente por riscos desnudos, sólo se encontraban, además del oficial y el explorador, el condenado, un hombre de boca grande y aspecto estúpido, de cabello y rostro descuidados, y un soldado, que sostenía la pesada cadena donde convergían las cadenitas que retenían al condenado por los tobillos y las muñecas, así como por el cuello, y que estaban unidas entre sí mediante cadenas secundarias. De todos modos, el condenado tenía un aspecto tan caninamente sumiso, que al parecer hubieran podido permitirle correr en libertad por los riscos circundantes, para Ilamarlo com un simple silbido cuando llegara el momento de la ejecución. (J RW) 
- É um aparelho singular - disse o oficial ao explorador, e contemplou com certa admiração o aparelho, que lhe era tão conhecido. 0 explorador parecia ter aceito apenas por cortesia o convite do comandante para presenciar a execução de um soldado condenado por desobediência e insulto aos seus superiores. Na colônia penal não era tampouco muito grande o interesse suscitado por esta execução. Pelo menos, nesse pequeno vale, profundo e arenoso, cercado totalmente por campos nus, apenas se encontravam, além do oficial e do explorador, o condenado, um homem de boca grande e aspecto estúpido, de cabelo e rosto descuidados, e um soldado, que sustinha a pesada cadeia de onde convergiam as pequenas cadeias que retinham o condenado pelos tornozelos e as munhecas, assim como pelo pescoço, e que estavam unidas entre si mediante cadeias secundárias. (TG)

Já em relação à tradução de Torrieri Guimarães de A muralha da China, com trinta e seis textos (entre eles "Descrição de uma luta"), temos a seguinte situação: o conteúdo corresponde ao quinto volume de Gesammelte Schriften, na organização de Max Brod, publicado em 1936 pela H. Mercy Sohn de Praga, ${ }^{5}$ que leva o título de Beschreibung eines Kampfes: Novellen, Skizzen, Aphorismen aus dem Nachlass. Esse volume, além de um apêndice com três fragmentos e o conto "La leva", foi lançado em 1953 pela Emecé com o título de La muralla china - cuentos, relatos, escritos, em tradução de Alfredo Pippig e Alejandro Ruiz Guiñazú para a coleção "Grandes Novelistas". A edição argentina, porém, por alguma razão excluiu o conto "Der Geier" ( "O abutre"), que também saíra pela Losada em 1938. A edição brasileira da L. E. L. o inclui, mas, por outro lado, exclui três parábolas constantes no original da Schocken e na tradução da Emecé: "La verdad sobre Sancho Panza", "El silencio de las sirenas" e "Prometeo".

Diga-se de passagem que a tradução de "O abutre" atesta que Torrieri e a L.E.L. recorreram ao volume da Losada para além dos três contos já exaustivamente comentados. Pois ela vem fielmente baseada em "Le buitre", na tradução de lavra, esta sim efetiva, de J orge Luis Borges.

\footnotetext{
${ }^{5}$ Quando o governo nazista proibiu a publicação de obras de Kafka (e de Brod) na Alemanha, o editor Schocken transferiu parte de suas operações editoriais para Praga, com Heinrich M. Sohn.
} 
Vale notar que A muralha da China é uma das raras edições em que a L.E.L. estampa na página de créditos algum tipo de referência bibliográfica. Temos: "Título da obra em alemão: Beschreibung eines Kampfes". Aqui também, e desta vez no prefácio do volume, Torrieri Guimarães avoca a si a responsabilidade pela compilação e seleção dos textos. Afirma ele em prefácio: "Aqui está, nesta compilação que fizemos (...)", "Assim é que, nas histórias que selecionamos aqui (...)" [negritos meus] - afirmações que, tal como no caso de A colônia penal, só se poderiam considerar válidas se se admitisse que, aqui, a exclusão das três breves parábolas chegaria a configurar algum tipo de recorte minimamente original na composição e organização da coletânea.

E neste ponto cabe a provável explicação para a exclusão dos dois diálogos de "Descrição de uma luta" do volume A colônia penal, como dissemos acima, em todo o restante tão fiel à organização de Brod via Wilcock. 0 critério que Brod adotou para organizar Beschreibung eines Kampfes: Novellen, Skizzen, Aphorismen aus dem Nachlass, o quinto volume das obras reunidas, foi o de reunir num só volume as novelas, parábolas, aforismos e fragmentos ainda inéditos. Como os dois diálogos de Beschreibung eines Kampfes publicados em vida - "Gespräche mit dem Beter" e "Gespräche mit dem Betrunkenen" - já tinham saído no primeiro volume, naturalmente voltaram a sair também na narrativa completa, publicada postumamente no quinto. A L.E. L., não tendo nem de longe qualquer pretensão de apuro editorial, decerto considerou que não faria muito sentido repeti-los em dois volumes lançados com poucos meses de intervalo entre si, A muralha da China e A colônia penal, e provavelmente foi por tal razão que excluiu os diálogos desta segunda (aliás, lançada pela L.E.L. depois d'A muralha).

Quanto ao uso da tradução de Pippig e Guiñazú em espanhol para a tradução de Torrieri, apresentemos mais uma rápida amostra a título elucidativo, extraída de "Abogados" / "Advogados":

Por sobre todas las singularidades, lo que más me recordaba a un tribunal era un retumbar ininterrompido que se oía a lo lejos; no podia decirse de qué dirección provenía; colmaba a tal punto todos 
Ios ambientes, que podia pensarse procedía de todas partes; 0, lo que parecia más exacto todavía, que el sitio donde casualmente estaba uno fuera el verdadeiro sitio de aquel retumbar; pero seguramente aquello era un error, pues el rumor venía de lejos. $(P \& G)$

Por cima de todas as singularidades, o que mais me lembrava um tribunal era um retumbar ininterrupto que ouvia ao longe; não se podia dizer de que direção provinha; enchia a tal ponto todos os ambientes, que se podia pensar que vinha de todos os lados; ou, 0 que ainda parecia mais exato, que o local onde casualmente estava alguém fosse o verdadeiro local daquele retumbar; mas certamente aquilo era um erro, pois o rumor vinha de longe. (TG)

Para uma última demonstração sobre o uso do espanhol como língua de interposição nas traduções de Torrieri, vejamos mais dois brevíssimos trechos, o primeiro de El castillo, em tradução de D. J . Vogelmann para a Emecé (1949)/ O castelo, em tradução de Torrieri Guimarães para a Tema (1965); o segundo de Carta a mi padre y otros escritos, em tradução de Carlos Félix Haeberle, pela Emecé (1955)/ Carta a meu pai, em tradução de Torrieri Guimarães para a L.E.L. (1965):

Ya era de noche cuando K. Ilegó. La aldea yacía hundida en la nieve. Nada se veía en la colina; bruma y tinieblas la rodeaban; ni el más debil resplandor revelaba el gran castillo. Largo tiempo K. se detuvo sobre el puente de madera que del camino real conducía a la aldea, con los ojos alzados al aparente vacío. (DJ V)

Era noite já quando K. chegou. A aldeia permanecia imersa na neve. Não se via nada da colina; bruma e trevas rodeavam-na; nem o mais flébil resplendor revelava o grande castelo. Por muito tempo $\mathrm{K}$. deteve-se sobre a ponte de madeira que do caminho real levava à aldeia, com os olhos erguidos para o aparente vazio. (TG)

E: 
Querido padre, una vez me preguntaste por qué afirmaba yo que te temía. Como de costumbre, no supe qué responderte, en parte precisamente por el temor que me infundes (...) (CFH)

Querido pai: Perguntaste-me certa vez por que motivo eu afirmava que te temia. Como de hábito, não soube o que te responder, em parte exatamente pelo temor que me infundes (...) (TG)

Quero reiterar que nada há de ilícito em traduções indiretas. Se venho me delongando sobre o tema, é no exclusivo intuito de desfazer com meridiana clareza o engano corrente de que Torrieri Guimarães teria se valido do francês para verter Kafka e, em paralelo, sepultar definitivamente qualquer eventual resquício de incerteza em torno dessa questão. E tal intuito, por sua vez, só guarda alguma relevância porque, como dissemos, foram as traduções de Torrieri que compuseram a primeira grande onda de publicação de Kafka entre nós, tornando-se assim um dos traços constitutivos da kafkiana brasileira. ${ }^{6}$

De modo geral, portanto, e como se depreenderá nitidamente da cronologia apresentada na próxima seção, podemos dizer que a kafkiana brasileira, no que se refere à língua de partida, divide-se em três vertentes dominantes. Após a fase inicial bastante salteada e indistinta (1946-1963), temos a partir de 1964 a fase de tradução indireta basicamente por interposição do espanhol (L.E.L., com Torrieri Guimarães); nos anos 1970, a fase de tradução indireta sobretudo por interposição do inglês (Nova Época, com vários tradutores); a partir dos anos 1980, num período que ultrapassa o escopo deste artigo, a tradução direta do original alemão (sobretudo por obra de Modesto Carone, mas também, em data mais recente, por outros tradutores, como Marcelo Backes).

O uso do francês como língua de interposição foi tão esporádico que, a meu ver, não chega a se configurar como elemento de maior peso dentro da

\footnotetext{
6 Já o exame dos motivos pessoais que teriam levado Torrieri Guimarães a alimentar tal imprecisão e até a encenar uma pequena farsa perante imprensa e academia escapa ao âmbito desta pesquisa. Quiçá não passasse de mera e singela vaidade intelectual, por talvez considerar o francês "mais chique", "mais respeitável" ou algo assim.
} 
kafkiana brasileira: entre suas poucas ocorrências, cabe menção especial apenas ao caso de Geir Campos, com Parábolas e fragmentos (Civilização Brasileira, 1956), talvez o primeiro livro de Kafka publicado no Brasil, como veremos adiante.

\section{Kafka brasileiro}

Passemos, por fim, à apresentação cronológica das traduções de Kafka no Brasil, desde as primeiras que pude localizar, a partir de 1946 até 1979.

\section{Primórdios, anos 1940}

Nas seções culturais de nossos principais jornais na primeira metade do século XX, não se encontram menções a Kafka senão a partir de 1941.

A estreia se parece ter dado em 27 de abril de 1941, quando o carioca Diário da Manhã publica um longo artigo de Otto Maria Carpeaux, "Franz Kafka e o Mundo Invisível", escrito em francês e traduzido por Carlos G. Lima Cavalcanti, e que será publicado no ano seguinte em seu livro de ensaios A cinza do purgatório.

Quanto aos escritos de Kafka, o primeiro traduzido e publicado no Brasil foi, ao que tudo indica, "Um artista do trapézio". Saiu na Revista da Semana, ano 47, n. 13, de 30 de março de 1946, sem especificar fontes nem tradutor.

A seguir temos o conto "Cruza". Saiu em agosto de 1946, no número de estreia da revista Agora, de Goiânia, fundada por Oscar Sabino Jr. e Afonso Félix de Sousa.

Em 18 de agosto do mesmo ano, o jornal carioca Correio da Manhã publica "A porta da lei", em tradução de "A.C.M." 
Em 25 de agosto do mesmo ano, saem duas parábolas traduzidas por Cláudio Tavares Barbosa, publicadas em Letras e Artes, o suplemento dominical do jornal carioca A Manhã. São elas "Prometeu" e "Uma confusão quotidiana".

Em março de 1947, no nono número da célebre e efêmera revista curitibana J oaquim, fundada por Dalton Trevisan e Erasmo Piloto, temos um episódio de América vertido por Waltensir Dutra, bem como "Um cruzamento", "O vizinho" e "Parábolas", vertidos por Waltensir Dutra e Temístocles Linhares. $^{7}$

No número 10 da mesma J oaquim, em maio de 1947, temos " 0 advogado novato" e "A aldeia mais próxima", em tradução de Temístocles Linhares.

No já referido caderno cultural Letras e Artes, a edição de 24 de agosto de 1947 traz algumas parábolas e aforismos selecionados e traduzidos por Otto Maria Carpeaux.

Em 31 de agosto de 1947, o jornal Diário de Notícias publica “Um artista do trapézio", em tradução de Aurélio Buarque de Hollanda, especificando devidamente que a fez a partir do espanhol, na pretensa tradução de J orge Luis Borges.

Voltando à revista J oaquim, seu número 14, em outubro de 1947, traz "O só em Kafka", trechos de seu diário selecionados e traduzidos por Georges Wilhelm.

E, por fim, um breve registro em paralelo: ainda na Joaquim em seu número 18, de maio de 1948, temos uma tradução de Wilson Martins do episódio inicial d' 0 processo, em sua adaptação teatral em francês feita por André Gide e J ean-Louis Barrault.

Como se vê, foram o caderno cultural Letras e Artes e, sobretudo, a revista J oaquim que mais se detiveram nesses poucos anos sobre textos de Kafka. A tal ponto que, em 20 de fevereiro de 1949, numa breve nota, o Diário de Notícias comenta - porém com visível exagero - que praticamente todos os números da J oaquim traziam materiais de/ sobre Kafka. Na mesma nota, o

\footnotetext{
7 Sobre a J oaquim e os textos de Kafka, é precioso o levantamento de Miguel Sanches Neto (1998), no qual me baseei para os dados acima apresentados.
} 
resenhista menciona que as recém-criadas Cronos e Revista Branca, ambas do Rio de J aneiro, traziam algum conto de Kafka, sem especificar. Não tive acesso a essas duas publicações, mas fique registrada a menção a elas na grande imprensa.

Nota-se que a introdução de Kafka no Brasil se deu, portanto, em seções culturais de alguns jornais da imprensa carioca e em revistas disseminadas em alguns estados do país (Rio de J aneiro, Paraná e Goiás), num breve surto de poucos anos (1946-48), a partir de fontes variadas e nem sempre claramente especificadas.

Decorrerão quase dez anos até termos o primeiro Kafka em livro, como veremos a seguir.

\section{Os anos 1950}

0 ano de 1956 inaugura Kafka em livro no Brasil. A estreia, porém, é discreta e reservada a poucos, em edições especiais de baixa tiragem. São elas Parábolas e fragmentos e Metamorfose. Detenhamo-nos brevemente sobre elas.

Parábolas e fragmentos consiste numa pequena coletânea de 48 páginas, com seleção e tradução de Geir Campos por interposição do francês, que foi publicada na Coleção Maldoror da editora Civilização Brasileira, em seu selo de edições especiais para bibliófilos, a Philobiblion, numa tiragem restrita de 300 exemplares de luxo.

Metamorfose, em tradução de Brenno Silveira por interposição do inglês, como vimos na seção anterior, também foi publicada pela Civilização Brasileira no mesmo ano de 1956. Embora não tenha saído pelo selo para bibliófilos, era uma edição especial, com tiragem de apenas mil exemplares.

É difícil saber a qual dessas duas obras, Parábolas e fragmentos ou Metamorfose, cabe a anterioridade de publicação no ano de 1956. Pessoalmente, inclino-me para a edição da Philobiblion, até por ser tão restrita, sugerindo uma espécie de balão de ensaio em vista de alguma incerteza 
editorial quanto ao alcance comercial do autor, até então inédito no Brasil em formato de livro.

Ainda em 1956, temos "O médico rural" na antologia Titãs da literatura, vol. VII da coleção "Os titãs", editora El Ateneo do Brasil, 1956, em tradução de A. Barbosa Rocha.

Em 1957, sai pela Cultrix o já comentado "Um artista do trapézio" em Maravilhas do conto alemão, em tradução anônima feita a partir da tradução espanhola pretensamente borgiana.

Em 1959, em Maravilhas do conto universal, último volume da coleção de mesmo nome, a Cultrix publica "O jejuador", em tradução de Ligia J unqueira Caiuby.

Em formato de livro, são estas as publicações de Kafka nos anos 1950 que consegui rastrear. A título de curiosidade, vale lembrar o conto "Um faquir", traduzido por Paulo Rónai e Aurélio Buarque de Hollanda, publicado em 11 de janeiro de 1959 na coluna "Conto da Semana" do jornal Diário de Notícias (SPIRY, pp. 199), que virá a ser incluído nos anos 1980 no décimo volume da antologia Mar de histórias, organizada por ambos.

\section{Os anos 1960}

A partir dos anos 1960, temos uma divulgação mais sistemática e continuada da obra de Kafka no país, com traduções feitas por Torrieri Guimarães com base nas edições em espanhol publicadas na Argentina. Elas foram publicadas em dez volumes ao todo, lançados em rápida sucessão entre 1964 e 1965, pela L.E.L. e por um efêmero e malogrado selo seu, a Tema Edições, que teria sido criado expressamente para publicar as obras de Kafka. Os volumes não trazem o ano de edição, mas é possível situá-lo com razoável precisão a partir das notas de lançamento dadas na imprensa, sobretudo a carioca.

0 primeiro volume a sair foi uma breve seleta com o título Contos escolhidos, com oito textos: "Blumfeld, um solteirão", "A toupeira gigante", "Investigações de um cachorro", "Descrição de uma luta", "Sobre as questões 
da lei", "Um golpe à porta da granja", "O timoneiro" e "Advogados". Se alguma vez Torrieri chegou a organizar algum volume de Kafka, poderíamos com alguma boa vontade conceder que teria sido este... ${ }^{8}$

Logo a seguir, em questão de um mês ou pouco mais, sai 0 processo pelo selo Tema Edições.

Assim, para 1964 temos, por ordem de lançamento, Contos escolhidos, 0 processo (Tema) e Diário íntimo; em 1965, 0 castelo (Tema), A muralha da China, Carta a meu pai, Cartas a Milena, A colônia penal, América e Diários, em ordem aproximada de lançamento ao longo do ano. Foram sucesso de público e vários deles se mantiveram por vários meses na lista dos mais vendidos, publicada periodicamente pelo Jornal do Brasil, sendo que 0 processo foi incluído entre os mais vendidos de todo o ano de 1964.

Dando prosseguimento às publicações de Kafka no Brasil na década de 1960, a editora Perspectiva Iançou em 1967 um alentado volume chamado Entre dois mundos - a situação dos judeus vista por autores judeus, com 45 textos entre contos e ensaios, com seleção de J acó Guinsburg e Anatol Rosenfeld. Entre eles, há dois contos de Kafka: "Vista da galeria", na seção "Preconceitos", e "A construção de uma cidade", na seção "O novo mundo". Não há identificação do(s) tradutor(es). Consultada, a editora pôde apenas informar que a tradução fora feita diretamente do original.

Encerrando a década, em 1969 a Civilização Brasileira lança uma coletânea que, além de trazer a já conhecida "Metamorfose" na tradução de Brenno Silveira, apresenta duas novas retraduções: "Na colônia penal", por Leandro Konder, e "O artista da fome", por Eunice Duarte, ambas pela infrequente interposição do francês.

\footnotetext{
${ }^{8}$ Todos esses contos fazem parte de Beschreibung eines Kampfes (e de La muralla china argentina), que sairá no ano seguinte pela L.E.L. com o título de A muralha da China. Assim, o lançamento de Contos escolhidos parece indicar que talvez se tratasse de uma tradução em andamento, reunindo os textos que já estavam prontos.
} 
BotTMAnN, D. - Kafka no Brasil: 1946-1979

\section{Os anos 1970}

Em 1972, a editora Artenova lança uma coletânea curiosa: A solidão segundo... Ernest Hemingway, Carson McCullers, Franz Kafka, Ray Bradbury, J orge Luis Borges, com seleção, introdução, notas e tradução de Hermenegildo de Sá Cavalcanti. O conto de Kafka escolhido para integrar a coletânea foi "Na colônia penal".

Ainda em 1972, a Antologia humanística al emã, com seleção de Wolfgang Langenbucher, apresenta "O julgamento", excertos de "O processo" e "Diante da lei", em volume publicado pela Globo em coedição com a alemã Horst Erdmann Verlag. São vários tradutores, sem especificação das responsabilidades individuais.

A seguir, numa empreita de fôlego, a Nova Época Editorial se lança a uma sequência de novas traduções das obras de Kafka. As edições não trazem o ano de publicação e, ao contrário das edições da L.E.L., pouca ou nenhuma atenção receberam na grande imprensa. De todo modo, é certo que não são anteriores a $1972 .^{9}$

Essa iniciativa editorial traz dois elementos marcantes. O primeiro deles é que todas as suas traduções foram feitas a partir do inglês, caracterizando a década de 1970 como o período com predomínio desse idioma como língua de partida para a kafkiana brasileira. O segundo é que, na contracapa e nas edições que trazem orelha, tem-se em destaque o seguinte anúncio:

A NOVA ÉPOCA EDITORIAL Ltda.

Avenida Angélica, 55

S. Paulo

Comunica ao público em geral que adquiriu os DIREITOS AUTORAIS DE TRADUÇÃO, para o BRASIL PORTUGAL e todos os países de língua portuguesa das obras de:

FRANZ KAFKA

\footnotetext{
${ }^{9}$ A razão para tal afirmação pode parecer trivial, mas é sólida: em todas elas, junto ao endereço da editora consta o número do CEP. Como o código de endereçamento postal foi implantado em maio de 1971 e seu uso obrigatório só entrou em vigor em 1972, tal dado parece plenamente suficiente para estabelecer este ano como limite post quem.
} 
Ademais, na página de imprenta consta o título original da edição traduzida, o copyright da Schocken Books e respectivo ano, bem como os direitos autorais da edição brasileira da Nova Época. ${ }^{10}$

Como já sugerimos anteriormente, as edições de Kafka pela L.E.L. não dispunham de autorização de publicação no Brasil e daí a mirabolante história narrada por Torrieri Guimarães sobre a suposta licença gratuita, oralmente concedida por Max Brod ao proprietário da editora, Eli Behar. Não me surpreenderia se fosse a essa provável "pirataria" que a Nova Época, com seu comunicado ao público, tentava fazer frente.

Mesmo no caso da Nova Época, porém, nota-se que, a partir de certa altura, abandona-se o anúncio ao público sobre a aquisição dos direitos autorais e renuncia-se até mesmo a qualquer referência na página de imprenta seja aos direitos de publicação, seja ao título original da edição usada para a tradução. Difícil evitar a impressão de que a editora em algum momento decidiu enveredar pelo caminho mais fácil. Todavia, mesmo nesses casos, a língua de interposição continua a ser o inglês e, como se vê em Cartas a Milena, trazendo o prefácio de Willy Haas, segue a edição da Schocken.

Ao todo, a editora publicou dez títulos de Kafka. Na quarta capa, costumava constar uma relação de seus próximos lançamentos pela casa ou, mais tarde, de suas obras já publicadas. No entanto, as informações se sobrepõem e são contraditórias. Assim, no volume Carta a meu pai, têm-se como próximos lançamentos Colônia penal, O processo, A metamorfose, América, 0 castelo e A muralha da China. Porém, no volume A colônia penal, anunciam-se Carta a meu pai e 0 castelo como dois dos próximos lançamentos. E no volume $O$ castelo anunciam-se ainda, entre outros, os lançamentos de Carta a meu pai e Colônia penal. Nesses três volumes - A colônia penal, Carta

\footnotetext{
${ }^{10}$ Num pequeno alerta em paralelo, se eventuais leitores, pesquisadores e interessados em geral forem consultar as edições da Nova Época pela internet, irão se deparar várias vezes com algum ano de publicação de suas edições de Kafka. Todas essas datas se referem, na verdade, ao ano de publicação da obra em inglês, pela Schocken Books, como vem claramente especificado na página de imprenta dos vários volumes da Nova Época, e não devem induzir os consulentes a erro.
} 
a meu pai e 0 castelo -, um dos próximos lançamentos anunciados é A metamorfose. No entanto, na quarta capa de A metamorfose, lá constam aqueles mesmos três títulos na relação de próximos lançamentos, e por aí vai. Em suma, pelos dados constantes nos volumes publicados, é praticamente impossível saber não só o ano de edição, mas até mesmo uma ordem aproximada na sequência das publicações.

Por outro lado, na contracapa do volume A mural ha da China o que temos é uma relação das obras já editadas. São elas: Colônia penal, o processo, Cartas [sic] a meu pai, América, 0 castelo e A metamorfose. No volume seguinte, Cartas a Milena, temos a mesma relação, acrescida de A muralha da China. A única coisa que podemos inferir disso é que Cartas aos meus amigos e 0 diário íntimo de Kafka, os dois outros títulos de Kafka publicados pela Nova Época, saíram depois de Cartas a Milena e foram os últimos escritos kafkianos a ser lançados pela casa. Apesar de tantas imprecisões, há certos indícios que permitem supor que Carta a meu pai foi, se não o primeiro, um dos primeiros títulos publicados pela Nova Época.

Segue-se abaixo a relação dos volumes de Kafka e respectivos tradutores publicados pela Nova Época Editorial, por sequência alfabética e sem qualquer pretensão de ordenamento cronológico. 0 conteúdo, no geral, segue o das edições da Schocken americana. A principal exceção é "Metamorphosis", que integrava The Penal Colony: Stories and Short Prose, na tradução de Willa e Edwin Muir, que foi excluída da edição brasileira de A colônia penal para ser lançada em volume à parte.

A colônia penal, Syomara Cajado

A metamorfose, Syomara Cajado

A muralha da China: contos e máximas, sem créditos de tradução

América, D. P. Skroski

Carta a meu pai, Osvaldo da Purificação

Cartas a Milena, sem créditos de tradução

Cartas aos meus amigos, Osvaldo da Purificação 


\author{
O castelo, D. P. Skroski \\ O diário íntimo de Kafka, Osvaldo da Purificação \\ O processo, Syomara Cajado
}

Foram estes os títulos publicados pela Nova Época. À exceção de um ou outro título licenciado para terceiros (em particular 0 processo para o Círculo do Livro), a difusão dessas traduções não será nem remotamente comparável à difusão das de Torrieri Guimarães e, como dissemos, tampouco receberão grande divulgação na imprensa.

Ainda nos anos 1970, A metamorfose e 0 processo saem pela Tecnoprint com "texto em português" por Marques Rebelo. Aqui cabe um esclarecimento: "texto em português por/ de Fulano" é a expressão utilizada pela editora para designar adaptações feitas a partir de traduções previamente existentes. Parece-me necessário elucidar o significado de "texto em português" nas edições da Tecnoprint/Ediouro, em suas coleções voltadas para o público juvenil, tanto mais porque pesquisadores sérios como CRUZ, SANTOS e BRITO se sentiram tentados a considerar tais adaptações como traduções de direito próprio, o que, a meu ver, não é o caso. ${ }^{11}$

Por fim, uma dificuldade adicional nesse tipo de pesquisa bibliográfica consiste em rastrear escritos publicados em antologias gerais. Assim, não é absolutamente de se descartar que tenham saído outros contos, parábolas ou

\footnotetext{
${ }^{11}$ Ainda a propósito de A metamorfose, Marques Rebelo e Tecnoprint (futura Ediouro), embora escapando ao nosso quadro temporal, cabe aqui tentar elucidar outro provável equívoco. Cito: "Chama-nos a atenção o fato de que, neste ano de 1985, são publicadas outras duas traduções de A metamorfose. Uma reedição da tradução feita a partir do inglês por Brenno Silveira, publicada pela Civilização Brasileira, e uma nova tradução realizada também a partir do inglês por Enio Silveira e Marques Ribeiro Calouro, cuja publicação fica a encargo da editora Tecnoprint" (CELESTE, BRITO e SANTOS, p. 239).

Com efeito, existe um volume de escritos de Kafka selecionados e traduzidos do inglês por Ênio Silveira, proprietário e editor chefe da Civilização Brasileira: chama-se Contos, fábulas e af orismos e saiu por sua editora em 1983. Tradutor bissexto, Ênio jamais, até onde sei, traduziu Metamorfose - obra que, aliás, estava ativa no catálogo de sua editora desde 1956, na tradução feita por seu irmão Brenno Silveira. Por outro lado, sua concorrente Tecnoprint utilizava com frequência os préstimos de Marques Rebelo como adaptador para suas coleções, uma delas chamada justamente Calouro. Tendo a crer que a informação acima citada resultou de alguma eventual confusão dos pesquisadores entre pessoas, coleções e editoras.
} 
excertos de Kafka em antologias publicadas nessas décadas, e que estão ausentes deste levantamento.

\section{Conclusão}

Podemos resumir os dados acima apresentados da seguinte maneira: Kafka aportou no Brasil após o final da Segunda Guerra Mundial, de início em revistas e jornais, e apenas a partir de 1956 em livros. Sua ancoragem em termos mais significativos se dá em duas fases sucessivas nos anos 60 e 70, por vias maciças do espanhol e do inglês, respectivamente, em edições nem sempre muito primorosas. A despeito de fal has e irregularidades editoriais de maior ou menor monta, desde os anos 1960 praticamente todo o cânone kafkiano se encontra disponível em tradução brasileira, o que vem a se reforçar na grande onda de retraduções dos anos 1970. Nas décadas seguintes, a partir dos anos 1980, o que teremos é o efetivo amadurecimento de um processo de difusão de Kafka no Brasil que já vinha em franco, ainda que um tanto desigual, andamento. Iniciado tardiamente e de maneira esporádica, esse processo teve um fenomenal salto quantitativo nos anos 1960 que, mesmo a meio século de distância, ainda guarda fortes marcas na fortuna da kafkiana brasileira.

\section{Bibliografia}

BRITO, E.M. de. Quando a ficção se confunde com a realidade. São Paulo: Serviço de Comunicação Social, FFCHL/ USP, 2008. Aqui seguimos o texto de sua tese de doutorado. FFCHL/ USP, São Paulo, 2005.

CRUZ, C. Metamorfoses de Kafka. São Paulo: Annablume; Fapesp, 2007.

SANCHES NeTO, M. A reinvenção da província. Tese de doutorado. IEL/ UNICAMP, Campinas, 1998. 
SORRENTINO, F. El kafkiano caso de la Verwandlung que Borges jamás tradujo. In: Espéculo. Revista de Estudios Literários, n. 10, Madri, 1998. http:// www.ucm.es/ info/ especulo/ numerolo/ borg_tra.html

SoRrentino, F. No le deis al César lo que no es del César (dos partes). In: El Trujamán, $12 / 06 / 2000$. Centro

Virtual Cervantes. http:// cvc.cervantes. es/ truj aman/ anteriores/ junio_00/ 12062000.h tm

SousA, C.R. de, BRITO, E. M. de, e SANTOS, M.C. A recepção da obra de Franz Kafka no Brasil. In: Pandaemonium germanicum 9, 2005, pp.227-253.

SPIRY, Z. Paulo Rónai, um brasileiro made in Hungary. Dissertação de mestrado. FFCHL/ USP, São Paulo, 2009.

VIANNA, L.F. Editora plagiou traduções de clássicos. In Folha de S. Paulo, Caderno Ilustrada.

São Paulo,

04/ 11/ 2007.

http:/ / www1. folha. uol.com. br/ fsp/ ilustrad/ fq0411200716. htm

Para outros apontamentos sobre as traduções de Kafka no Brasil, ver BOTTMANN, D.

http:// naogostodeplagio. blogspot. com. br/ search/ label/ pesquisa\%20kafka 